\title{
Recessive Resistance Genes and the Oryza sativa- Xanthomonas oryzae pv. oryzae Pathosystem
}

\author{
Anjali S. Iyer-Pascuzzi and Susan R. McCouch \\ Department of Plant Breeding and Genetics, Cornell University, Ithaca, NY 14853, U.S.A. \\ Submitted 26 October 2006. Accepted 13 February 2007.
}

\begin{abstract}
Though recessive resistance is well-studied in viral systems, little is understood regarding the phenomenon in plant-bacterial interactions. The Oryza sativa-Xanthomonas oryzae pv. orzyae pathosystem provides an excellent opportunity to examine recessive resistance in plant-bacterial interactions, in which nine of $\mathbf{3 0}$ documented resistance $(R)$ genes are recessively inherited. Infestations of $X$. oryzae pv. oryzae, the causal agent of bacterial blight, result in significant crop loss and damage throughout South and Southeast Asia. Two recently cloned novel recessive $R$ genes, $x a 5$ and $x a 13$, have yielded insights to this system. Like their viral counterparts, these bacterial recessive $R$ gene products do not conform to the five commonly described classes of $R$ proteins. New findings suggest that such genes may more aptly be viewed as mutations in dominant susceptibility alleles and may also function in a gene-for-gene manner. In this review, we discuss recent accomplishments in the understanding of recessively inherited $R$ genes in the ricebacterial blight pathosystem and suggest a new model for the function of recessive resistance in plant-bacterial interactions.
\end{abstract}

Extensive work on race-specific resistance has resulted in the identification of more than 40 cloned plant resistance $(R)$ genes (Martin et al. 2003; McHale et al. 2006) to a wide variety of plant pathogens. Much of the focus in plant-bacterial interactions has centered around nucleotide binding site-leucine rich repeat (NBS-LRR) proteins, as these are the most common of the five classes of R proteins (Belkhadir et al. 2004; Martin et al. 2003; McHale et al. 2006). Intriguingly, though six bacterial blight (BB) $R$ genes have been cloned, only one, Xal, encodes an NBS-LRR protein (Yoshimura et al. 1998). Although recessive resistance is relatively uncommon in plantbacterial systems, nine of the approximately $30 \mathrm{Xa}$ genes are recessive (Table 1). The recent isolation of two of these, xa5 and $x a 13$, suggests that there are several previously undescribed types of $R$ genes and invites more questions. How do such $R$ genes contribute to resistance? Is resistance mediated by recessive $R$ genes equivalent to that mediated by dominantly inherited $R$ genes? In this review, we offer a brief introduction to the disease and then discuss recent developments in the study of recessive genes of this pathosystem. Finally, we

Current address for A. S. Iyer: Department of Biology, Duke University, Durham, NC 27712, U.S.A.

Corresponding author: Susan R. McCouch; E-mail: srm4@cornell.edu; Telephone: +1.607.255.0420; Fax: +1.607.255.6683. discuss a new model for their function. Nino-Liu and associates (2006) have provided a comprehensive discussion of both Xanthomonas oryzae pv. oryzae and the $X$. oryzae pv. oryzicola history and biology.

\section{Disease overview.}

Rice BB, caused by Xanthomonas oryzae pv. oryzae, was first reported by farmers in 1884 in the southern region of Japan (Devadath 1992; Mizukami and Wakimoto 1969). Though the disease was common throughout that region by 1910, it was not a severe rice disease in northern Japan and other Asian nations until the 1960s and 1970s (Mizukami and Wakimoto 1969). Many countries, including Nepal, India, and Sri Lanka, trace the first reported outbreak of the disease to the introduction of new, high-yielding (or 'modern') varieties that occurred at this time (Adhikari et al. 1994b; Mew 1993; Mew et al. 1992) (Table 2).

Major BB epidemics resulted in intensive breeding for disease resistance at the International Rice Research Institute (IRRI) (Mew et al. 1992). By 1981 IRRI had identified more than 1,000 varieties with resistance to the common Philippine pathotype of $X$. oryzae pv. oryzae (at that time, race 1; Mew et al. 1981, 1992). By the early to mid 1980s, most released IRRI varieties carried BB resistance; these accounted for more than $90 \%$ of the rice planted in the Philippines (Mew et al. 1992). BB is still found throughout nearly every Asian country. Accurate estimates of average yield losses are difficult to obtain, as these vary extensively by geographic region and season, but Upadhyay (1985) estimated that, in India, losses of 15 to $20 \%$ were common and, occasionally, as much as $40 \%$ of the crop was lost to BB.

Disease epidemiology and symptoms.

$X$. oryzae pv. oryzae is a rod-shaped gram-negative bacterium that enters rice leaves through wounds, stomata, or hydathodes (Mew 1987). The bacteria multiply in the epitheme, the tissue connecting the hydathodes to the xylem, to which they subsequently move and further multiply to infect the plant (Shen and Ronald 2002). BB is most severe in highly managed systems such as irrigated paddies or those with high $\mathrm{N}$ fertilizer applications. The disease is aggravated by warm, humid, and wet conditions. Symptoms of BB include water-soaking or gray lesions down the leaf, which often dry and turn chlorotic. Leaves often curve inward. In severe infections, bacteria ooze out of cracks or hydathodes.

Cultural control methods are important, but the primary and most effective means of control is through planting resistant cultivars. There are approximately 30 known $R$ genes to $\mathrm{BB}$ (Chu et al. 2006).To facilitate characterization of $X a$ genes and 
$X$. oryzae pv. oryzae isolates, IRRI developed a set of nearisogenic lines (NILs) in the 1980s. Each NIL contained a single $X a$ gene in the background of the susceptible cultivar IR24 (Ogawa et al. 1988). Using these isolines, six BB $R$ genes have been cloned (xa13, Chu et al. 2006; Xa27, Gu et al. 2005; xa5, Iyer and McCouch 2004; Xa21, Song et al. 1995; Xa1, Xa26, Sun et al 2004 and Yoshimura et al. 1998).

\section{$X$. oryzae pv. oryzae virulence.}

Like other gram-negative bacteria, $X$. oryzae pv. oryzae promotes disease and avirulence through type-III secreted effector proteins (Alfano and Collmer 2004; Gurlebeck et al. 2006). Based on similarity to known effector genes, eight homologs were identified in the recently sequenced $X$. oryzae pv. oryzae genome (Lee et al. 2005). Five were members of the avrBs3/pthA or TAL (transcription activator-like) family of effectors.
TAL effectors are found throughout the Xanthomonas genus and appear to be particularly important for $X$. oryzae $\mathrm{pv}$. oryzae virulence. In a diverse set of $X$. oryzae pv. oryzae strains from various countries, several carried at least one of the four major virulence effectors: $a v r X a 7$, pthXol, pthXo2, and pthXo3 (Yang and White 2004). Loss of avrXa7, pthXo1, pthXo2, and pthXo3 from $X$. oryzae pv. oryzae result in extremely reduced symptom development and bacterial growth (Bai et al. 2000; Swarup et al. 1991; Yang and White 2004).

Members of the TAL effector protein family are 90 to $97 \%$ identical and are typified by an N-terminal secretion signal and variable number of near-perfect repeats of a 34-amino acid sequence near the middle of the protein (Mudgett 2005). They have imperfect heptad leucine repeats, at least one nuclear localization signal (NLS), and an acidic activation domain (AAD) at the $\mathrm{C}$ terminus (Gurlebeck et al. 2006). Structurefunction studies have examined the domains of the TAL family

Table 1. Recessively inherited rice bacterial blight resistance genes ${ }^{\mathrm{a}}$

\begin{tabular}{|c|c|c|c|c|c|c|c|}
\hline Gene & Chm & Original donor & Resistance spectrum & Derived $^{b}$ & Comments/Durability & Cloned & Reference $^{c}$ \\
\hline$x a 5$ & 5 & DZ192 & $\mathrm{PXO}^{\mathrm{d}}$ races $1-3,5$ & $\mathrm{n}$ & $\begin{array}{l}\text { Stronger resistance in combi- } \\
\text { nation with other } X a \text { genes }\end{array}$ & yes & $\begin{array}{l}\text { Petpisit et al. } 1977 \\
\text { Iyer and McCouch } 2004\end{array}$ \\
\hline$x a 8$ & 7 & P1 231129 & $\begin{array}{l}\text { Moderately resistant to } \mathrm{PXO} \text { races } \\
1-3 \text {, resistant to } \mathrm{PXO} \text { race } 5\end{array}$ & $\mathrm{n}$ & NA & no & $\begin{array}{l}\text { Sidhu et al. } 1978 \\
\text { Singh et al. } 2002\end{array}$ \\
\hline$x a 13$ & 8 & BJ1 group & $\begin{array}{l}\text { PXO race } 6 \text {, susceptible to PXO } \\
\text { races } 1-5\end{array}$ & $\mathrm{n}$ & $\begin{array}{l}\text { Stronger resistance in combi- } \\
\text { nation with } \mathrm{X} a 4, x a 5, \mathrm{X} a 21\end{array}$ & yes & $\begin{array}{l}\text { Chu et al. } 2006 \\
\text { Ogawa et al. } 1987\end{array}$ \\
\hline xa15 & $\mathrm{NA}^{\mathrm{e}}$ & $\begin{array}{l}\text { M41(mutant of } \\
\text { Harebare) }\end{array}$ & Japanese isolates & $\mathrm{m}$ & Also termed $x a(\mathrm{~nm})$ & no & $\begin{array}{l}\text { Nakai et al 1988, 1990; } \\
\text { Ogawa } 11996\end{array}$ \\
\hline$x a 19$ & NA & XM5 & Japanese isolates & $\mathrm{m}$ & NA & no & Taura et al. 1991 \\
\hline$x a 20$ & NA & XM6 & PXO races 1-6 & $\mathrm{m}$ & NA & no & Taura et al. 1992 \\
\hline$x a 24$ & NA & $\begin{array}{l}\text { DV85, DV86, } \\
\text { Aus } 295\end{array}$ & PXO race 6 & $\mathrm{n}$ & NA & no & Khush and Angeles 1999 \\
\hline$x a 26 b$ & NA & $\begin{array}{l}\text { Nep Bha Bong } \\
\text { To }\end{array}$ & MR PXO races1-3, R PXO race 5 & $\mathrm{n}$ & NA & no & Lee et al. 2003 \\
\hline$x a 28$ & NA & Lota Sail & PXO86, races 2 and 5 & $\mathrm{n}$ & NA & no & Lee et al. 2003 \\
\hline
\end{tabular}

${ }^{a}$ Niño-Liu and associates (2006) provide a complete list of bacterial blight resistance genes.

${ }^{\mathrm{b}} \mathrm{n}=$ Allele derived naturally, $\mathrm{m}=$ allele derived from an induced mutant.

${ }^{\mathrm{c}}$ References refer to first known identification and, if available, first cloning or mapping.

${ }^{\mathrm{d}} \mathrm{PXO}=$ Philippine Xanthomonas oryzae pv. oryzae race.

${ }^{\mathrm{e}} \mathrm{NA}=$ not available.

Table 2. Rice bacterial blight in selected Asian countries

\begin{tabular}{|c|c|c|c|}
\hline $\begin{array}{l}\text { Country } \\
\text { or Region }\end{array}$ & First Reported Occurrence of BB & Average $\%$ disease loss/epidemics & Distribution throughout the country \\
\hline China & $\begin{array}{l}\text { At least by the } 1950 \text { s } \\
\text { (Mizukami and Wakimoto 1969) }\end{array}$ & 'Severe' disease loss (Mew 1987) & $\begin{array}{l}\text { Widespread since introduction of hybrids } \\
\text { (Mew 1993) }\end{array}$ \\
\hline India & $\begin{array}{l}\text { Associated with introduction of TN-1 } \\
\text { in } 1965 \text { in several states, first } \\
\text { noticed in Maharashtra in } 1951 \\
\text { (Sridhar 2002) }\end{array}$ & $\begin{array}{l}\text { Most severe in the Northern states of Punjab and } \\
\text { Uttar Pradesh. Major epidemics in the Punjab } \\
\text { 1980s and in } 1995 \\
\text { (Kang and Singh 1987, Raina et al. 1981) }\end{array}$ & $\begin{array}{l}\text { Considered a problem everywhere except } \\
\text { Assam, Kerala } \\
\text { (Sridhar 2002; Upadhyay 1985) }\end{array}$ \\
\hline Japan & $\begin{array}{l}1884 \\
\text { (Mizukami and Wakimoto 1969) }\end{array}$ & $\begin{array}{l}20 \text { to } 30 \% \text { in moderately infected fields } \\
\text { (Mizukami and Wakimoto 1969) }\end{array}$ & $\begin{array}{l}\text { Throughout the country, in approximately } \\
10 \% \text { of total acreage grown to rice } \\
\text { (Mizukami and Wakimoto 1969) }\end{array}$ \\
\hline Nepal & $\begin{array}{l}\text { 1968, Kathmandu Valley } \\
\text { (Adhikari et al.1994a) }\end{array}$ & $\begin{array}{l}\text { Major epidemics in } 1979 \text { and 1987, yield losses up } \\
\text { to } 26 \% \text { (Adhikari et al 1994a). In a survey of } 32 \\
\text { districts, seven had average field infections } \\
\text { greater than } 50 \%, 6 \text { had } 25-50 \%, 16 \text { between } 10- \\
25 \% \text { and } 2 \text { less than } 10 \% \\
\text { (Adhikari and Shrestha 1990) }\end{array}$ & Widespread (Adhikari and Shrestha 1990) \\
\hline Pakistan & 1976 (Mew and Majiid 1977) & Considerable yield loss (Akhtar and Akram 1987) & Widespread (Akhtar and Akram 1987) \\
\hline Philippines & $\begin{array}{l}\text { Since the } 1950 \mathrm{~s} \\
\text { (Mew et al. 1992) }\end{array}$ & $\begin{array}{l}\text { Major epidemics in the } 1960 \text { s, no large-scale or } \\
\text { severe epidemics since the introduction of } X a \text { genes } \\
\text { (Mew et al. 1992) }\end{array}$ & Widespread (this study) \\
\hline Sri Lanka & 1950s (Ochiai et al. 2000) & $\begin{array}{l}\text { Serious damage to rice production since } 1967 \\
\quad \text { (Ochiai et al. 2000) }\end{array}$ & Widespread (Ochiai et al. 2000) \\
\hline Thailand & $\begin{array}{l}1963 \text { in Pathum Thani Province } \\
\text { (Eamchit and Mew 1981) }\end{array}$ & $\begin{array}{l}8 \text { to } 16 \% \text { empty grains in central Thailand } \\
\text { (Sirisantana et al. 1984) }\end{array}$ & NA \\
\hline Vietnam & NA & $\begin{array}{l}\text { Only severe in rainy season } \\
\text { (van Kim et al. 1981) }\end{array}$ & $\begin{array}{l}\text { Limited to certain regions } \\
\text { (van Kim et al. 1981) }\end{array}$ \\
\hline
\end{tabular}


members that contribute to either virulence or avirulence. Results indicate that the AAD, NLS, and repeat regions are all important for both avirulence and virulence specificities (Szurek et al. 2001; Yang and White 2004; Yang et al. 2000). For example, mutations in the AAD were found to disrupt the avirulence activity of AvrXa10 in rice (Zhu et al. 1998, 1999), while loss of the NLS resulted in loss of avirulence and virulence activities of AvrXa7 (Yang et al. 2000).

Due to their transcription factor-like motifs, several studies have examined the possibility that these proteins play a role in host transcription (Marois et al. 2002; Szurek et al. 2001; Yang et al. 2000; Zhu et al. 1998, 1999). AvrXa10 and AvrXa7, both from $X$. oryzae pv. oryzae as well as AvrBs3 from X. campestris pv. campestris are localized to the nucleus (Szurek et al. 2001; Yang et al. 2000; Zhu et al. 1998). AvrXa10 can activate transcription in yeast and Arabidopsis (Zhu et al. 1998, 1999); AvrXa7 binds to AT-rich DNA sequences (Yang et al. 2000), and AvrBs3 interacts with nuclear transport protein importin alpha (Szurek et al. 2001) and can induce the transcription of several genes in pepper (Marois et al. 2002). Members of this family may also promote virulence through the suppression of plant defenses. AvrXa7 and AvrXa10 suppress the nonhost hypersensitive response (HR) in tobacco as well as the expression of certain PR (pathogen-responsive) genes (Fujikawa et al. 2006).

\section{Recessive plant $\boldsymbol{R}$ genes.}

Though most $R$ genes in bacterial and fungal systems show dominant inheritance, recessive resistance is fairly common in viral systems, accounting for slightly less than half of all known viral $R$ genes (Kang et al. 2005b). Strikingly, most of those isolated to date are homologs of the same gene, translation initiation factor eIF4E (Diaz-Pendon et al. 2004; Kang et al. 2005b). This gene provides resistance to several viruses in the family Potyviridae and has been identified in the dicots pepper ( $p v r l)$, pea $(s b m l)$, lettuce ( $m o l)$, tomato (potl), and melon (nsv) and in the monocot barley (rym4/5) (Kang et al. 2005b; Robaglia and Caranta 2006). Additionally, translation initiation factor $e I F 4 G$ is responsible for resistance of rice to Yellow mottle virus (Albar et al. 2006) and in Arabidopsis to Cucumber mosaic virus and Turnip crinkle virus (Yoshii et al. 2004). Though the $R$ genes mentioned above produce different resistance phenotypes (for example, inhibition of cell-to-cell movement or viral replication), several studies have shown that resistance is due to mutations in eIF4E or eIF(iso)4E (DiazPendon et al. 2004; Kang et al. 2005b; Robaglia and Caranta 2006). Although the exact role of eIF4E in the potyvirus infection cycle is unknown, it is possible that eIF4E interacts with a small viral protein known as VPg (viral protein genomelinked) during infection and a lack of interaction results in the inability of the virus to complete its life cycle and successfully infect the plant (Kang et al. 2005a and b; Robaglia and Caranta 2006).

In bacterial and fungal plant-pathogen interactions, there are currently only four cloned recessively inherited $R$ genes: barley mlo (Buschges et al. 1997), Arabidopsis RRS1-R (Deslandes et al. 2002), rice xal3 (Chu et al. 2006), and xa5 (Iyer and McCouch 2004; Jiang et al. 2006), all of which encode structurally different proteins. The mlo allele encodes a $60-\mathrm{kDa}$ seven-transmembrane protein that provides broad-spectrum resistance to all known isolates of the powdery mildew pathogen Blumeria graminis f. sp. hordei (Buschges et al. 1997). RRS1-R is a unique member of the NBS-LRR class of R products, with a WRKY transcription factor domain in its $\mathrm{C}$ terminus (Deslandes et al. 2002). Though genetically defined as a recessive $R$ gene in ecotype Niederzenz (Nd-1), RRS1-R behaves as a dominant $R$ gene when transformed into Arabidopsis Colombia ecotype, and resistant plants transformed with
$R R S 1-S$ remain resistant, suggesting that $R R S 1-R$ is not a true recessive allele (Deslandes et al. 2002). In this review, we will focus on two examples of recessively inherited, race-specific resistance mediated by genes in the BB system.

\section{Host plant resistance to BB: Not a 'typical' pathosystem?}

xa5 encodes TFIIA-gamma. The xa5 allele provides racespecific resistance to $X$. oryzae pv. oryzae. Based on candidate gene analysis, xa5 appears to be unique among $R$ genes because it does not fall into any of the predicted $R$ gene product classes (Blair et al. 2003). Map-based cloning revealed that $x a 5$ encoded the small subunit of transcription factor IIA (TFIIA $\gamma$ ) (Iyer and McCouch 2004). A 2-nucleotide substitution at position 39 in the second exon of the gene resulted in an amino acid change from valine (V39) in susceptible cultivars to glutamic acid in resistant. Association analysis of 27 resistant and nine susceptible cultivars from the Aus-Boro group of rices identified a single haplotype among all resistant varieties tested and two haplotypes among the susceptible cultivars. All resistant cultivars contained glutamic acid at position 39; all susceptible cultivars contained valine, and some had an additional silent substitution (Iyer and McCouch 2004). There was no differential expression of either the $x a 5$ or Xa5 allele in response to infection. Transformation of the dominant susceptible allele from IR24, an indica, into a resistant background resulted in diseased plants, as measured by lesion length and bacterial population growth (Jiang et al. 2006; A. Iyer-Pascuzzi and S. R. McCouch, unpublished). We will use the designation $X a 5^{R / S}$ to refer to the locus (containing either allele) and $x a 5$ or $X a 5$ to refer specifically to the resistant or susceptible alleles, respectively.

Structure and function of TFIIA-gamma. TFIIA is one of several general transcription factors (GTF) that work with RNA polymerase II to transcribe DNA (Hampsey 1998; Orphanides et al. 1996; Roeder 1996). It is an extremely wellconserved protein, necessary for accurate development in both the animal and plant kingdoms (Aoyagi and Wassarman 2000; Burke et al. 1990). In yeast, TFIIA is composed of two subunits, Toa1 and Toa2, while in plants and animals, it has three: $\propto$ and $\beta$ (homologous to Toa1) and $\gamma$ (homologous to Toa2). The $\propto$ and $\beta$ subunits are translated as one long polypeptide and are subsequently cleaved. TFIIA stimulates transcription (Kobayashi et al. 1998; Ozer et al. 1994, 1996; Stargell and Struhl 1995; Stargell et al. 2000), is involved in promoter selectivity (Hampsey 1998; Orphanides et al. 1996), and stabilizes the binding of transcription factor IID (TFIID; another GTF necessary for transcription by RNA polymerase II) to DNA (Chi et al. 1995; Lieberman and Berk 1994; Wang et al. 1992). TFIIA is an unusual GTF in that it is not necessary for activated transcription of all genes in typical conditions, and promoters vary in the degree to which they require this GTF (Liu et al. 1999 Ozer et al. 1998b). Structure analysis of the entire TFIIA protein ( $\propto, \beta$ and $\gamma$ subunits) showed that it is composed of two domains: i) a $\beta$ barrel that contacts DNA and the TATA-box binding protein (TBP) and ii) a four-helix bundle (4HB) that faces away from the DNA (Fig. 1) (Bleichenbacher et al. 2003; Geiger et al. 1996; Tan et al. 1996). Not unexpectedly, the $4 \mathrm{HB}$ is composed of four major $\propto$-helices, two within the large $\propto / \beta$ subunit and two within the small $\gamma$ subunit.

Mutational studies in yeast have shown that nucleotide changes in the $4 \mathrm{HB}$ region affect transcription and growth and disrupt interactions with transcription-associated factors (Kang et al. 1995; Kraemer et al. 2001; 2006; Liu et al. 1999; Ma et al. 1996; Robinson et al. 2005; Warfield et al. 2004). Intriguingly, the critical mutation for $x a 5$-mediated resistance resides within an evolutionarily well-conserved hydrophobic patch within helix 3 of the $4 \mathrm{HB}$ in Toa2 (Fig. 1) (Kraemer et al. 
2001; 2006). Though yeast carries glutamic acid at the corresponding position to OsTFIIA $\gamma$ V39, mutation of this amino acid has no effect on Saccharomyces cerevisae growth (Kang et al. 1995).
There are two copies of TFIIA $\gamma$ in rice, one on chromosome 1 (OsTFIIA $\gamma 1)$ and another on chromosome 5 (OsTFIIA $\gamma 5 /$ $\left.X a 5^{R / S}\right)$. The coding regions of the Xa5 and OsTFIIA $\gamma 1$ alleles are $79 \%$ identical (86\% identical at the protein level). The dupli-

A

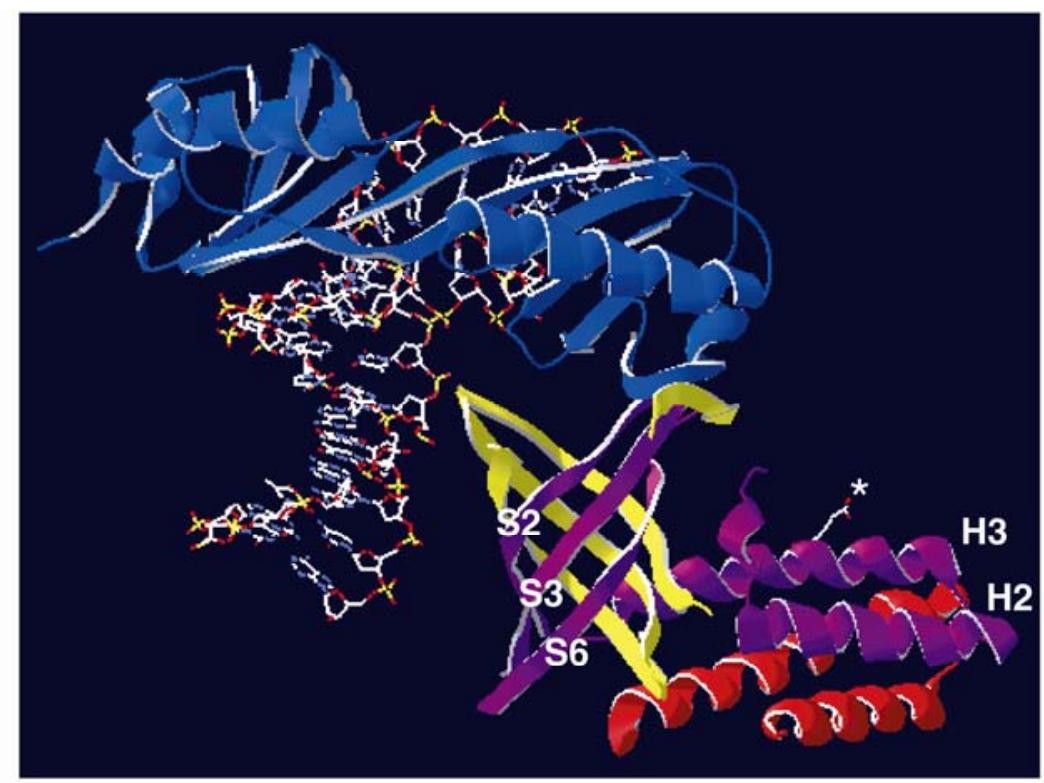

B $0.52 \operatorname{iv} 25$ 2. $m a y s t$ $0 . s$ atival 2. $m a y s \ddagger$ Arabidopsis H. $s$ pien R.rorvegicus D.mel mogaster S. cererisiat

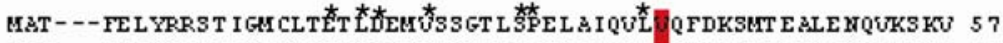
MAT - - FEL YRRST I GM CLTE TLDEMUSHGTL SPEL A IQUL VOFKSMT D ALEKQUKS KV 57 MAT - - FEL YRRS T IGM CLTDT LDDMUSSGAL SPE L A IQUL QFDKSMT S ALE HQUKSKU 57 MAT---FEL YRRST IGT CLTET LDEL USSGAUSPEL A IQUL VQFDKSMT E ALEMQUKS KU 57 MAT - - FEL YRRST I GM CLTET LDEMUOSGT L SPE L A I QUL VOFDKSMT E ALE SOUKT KU 57 -MA---YQL YRUT TL GK SLQES LDEL IQSQQ ITPQL ALQUL QFDKA IM AAL AQRURNRU 56 -MA---YQL YRAT TL G:A:TQQESLDEL IQSQQ ITPQL AL QUL LQFDKA IM S AL AQRURARU 56 -MS---YQL YRMT TL GNTLQESLDEL IQYGQ ITPGL AFKUL Q QFNS IMMALM QRUKARU 56

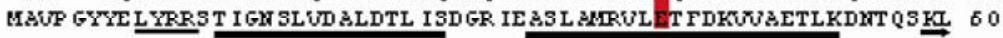
$\begin{array}{llll}\text { Helix } 1 & \text { Helix } 2 & \text { Helix } 3 & \text { S1 }\end{array}$

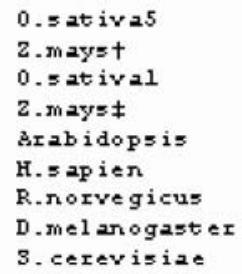

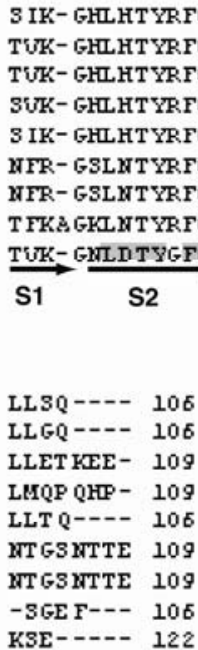

Fig. 1. A, Model of the Saccharomyces cerevisae crystal structure of TFIIA-TATA-box binding protein (TBP)-DNA (Bleichenbacher et al. 2003; Geiger et al. 1996; Tan et al. 1996). Blue $=$ TBP, yellow = region of Toal homologous to the $\beta$ chain of the large subunit in plants and animals, red $=$ region of Toa1 homologous to the $\propto$ chain of the large subunit, and purple $=$ Toa2. The four-helix bundle (4HB) is composed of two helices from Toa1 and the two larger helices from the $\mathrm{N}$ terminus of Toa2. The amino acid homologous to the critical mutation in Xa5 is starred; the side chain is shown. Modeled with SWISS PDBview and coordinates from the protein data bank file 1NH2 (Bleichenbacher et al. 2003). B, Alignment of TFIIA $\gamma$ from upper and lower eukaryotes. Secondary structures are denoted with underlines $(\mathrm{H}=\propto$-helices) or arrows ( $\mathrm{S}=\beta$-strands). The two $\propto$ helices and three $\beta$ strands contributing to the $4 \mathrm{HB}$ and $\beta$ domains, respectively, are labeled in both this section and in section A. The critical mutation for Xa5 is highlighted in red. Residues in contact with TBP are highlighted in gray (Geiger et al. 1996). Mutations in this region, particularly Y69 and W76, result in complex instability, transcription defects, or conditional viability or lethality, singly or in combination, in yeast (Ozer et al. 1996, 1998b; Stargell and Struhl 1995). The interaction with transcription-associated factors and other proteins typically occurs through the $\mathrm{N}$ terminus. Functionally important residues in this region, identified by single-point mutations to alanine or leucine in yeast, are starred (Kraemer et al. 2006; Ozer et al. 1996, 1998a; Warfield et al. 2004). In yeast, mutation of any 10 constitutive residues in Toa2 except the nonconserved region results in lethality. $\dagger$ indicates the TFIIA $\gamma$ ortholog of OsTFIIA $\gamma 5$ and $\ddagger$ indicates the TFIIA $\gamma$ ortholog of OsTFIIA $\gamma 1$. 
cation seems to be exclusive to monocots, as investigation of TFIIA $\gamma$ expressed sequence tags and cDNAs in GenBank revealed that dicots, such as Arabidopsis and citrus, have only one copy, while all monocots examined (rice, barley, oat, maize, wheat, and sorghum) have at least two copies (A. IyerPascuzzi and S. R. McCouch, unpublished). Additionally, all plant TFIIA $\gamma$ predicted proteins examined, including OsTFIIA $\gamma 1$, are similar to the susceptible allele product Xa5 in that they contain valine or a conservative substitution such as leucine or isoleucine at the variable amino acid position.

Phylogenetic analysis suggests that $X a 5^{R / S}$ may be ancestral to OsTFIIA $\gamma 1$. The evidence is based on the fact that $X a 5^{R / S}$ is more closely related to the small subunit of Arabidopsis TFIIA than to the rice paralog on chromosome 1 (Jiang et al. 2006). In further support of this, using the published X-ray crystal structure (Bleichenbacher et al. 2003) of the human TFIIATBP-DNA complex as a template, Jiang and associates (2006) used homology modeling to predict the X-ray crystal structure of $\mathrm{Xa} 5^{\mathrm{R} / \mathrm{s}}$ and OsTFIIA $\gamma 1$. The structures of $\mathrm{Xa} 5$ and $\mathrm{xa} 5$ were very similar, with a root mean square deviation (rms) of only $.024 \mathrm{~nm}$. However, they differed more from the OsTFIIA $\gamma 1$ structure $(\mathrm{rms}=.056 \mathrm{~nm}$ for Xa5) than from human TFIIA $\gamma$ (rms $=.0405$ and $.0397 \mathrm{~nm}$, for Xa5 and xa5, respectively). This was despite higher amino acid sequence similarity between $\mathrm{Xa} 5^{\mathrm{R} / \mathrm{S}}$ and OsTFIIA $\gamma(86 \%)$ than between $\mathrm{Xa} 5^{\mathrm{R} / \mathrm{S}}$ and human TFIIA $\gamma$ (approximately 47\%) (Jiang et al. 2006). These results all indicate that $\mathrm{Xa} 5^{\mathrm{R} / \mathrm{S}}$ is ancestral to OsTFIIA $\gamma 1$.

Function of $\mathrm{xa} 5$. Whether Xa5 ${ }^{\mathrm{R} / \mathrm{S}}$, TFIIA $\gamma 1$, or both function as the small subunit of TFIIA is not yet known, though the observation that the functional single-copy Saccharomyces cerevisae allele carries glutamic acid at the corresponding position to the $x a 5$ resistant allele suggests that this amino acid does not disrupt its essential function. Further, reverse transcription-polymerase chain reaction analysis of TFIIA $\gamma 1$ and $X a 5^{R / S}$ expression in different organs of the rice plant showed that both genes were expressed in leaves, stems, and roots, but only $X a 5^{R / S}$ was expressed in panicles (Jiang et al. 2006). This suggests that $\mathrm{Xa} 5^{\mathrm{R} / \mathrm{S}}$ may play a critical role in DNA transcription, particularly at or after the reproductive stage.

How might $\mathrm{xa} 5$, as TFIIA $\gamma$, provide resistance to $X$. oryzae pv. oryzae? Jiang and associates (2006) suggested that the resistant allele product xa5 may bind to transcriptional activators more tightly than to repressors, allowing the activation of genes important for defense, while the susceptible $\mathrm{Xa5}$ allele product may preferentially bind to activators of defense silencing genes. Alternatively, TFIIA $\gamma$ was recently shown to play a role in the oxidative stress response in yeast (Kraemer et al. 2006). Since this response is an important part of the plant defense response, it is possible that $x a 5$ mediates resistance in part through this pathway. However, based on recent results from our lab (A. Iyer-Pascuzzi and S. R. McCouch, unpublished), we propose that xa5-mediated resistance is a passive process that relies on secondary or basal defenses. In this scenario, we hypothesize that the valine to glutamic acid substitution in xa5 would prevent it from productively interacting with any bacterial proteins, but the susceptible allele product Xa5 would do so. This interaction could lead to the activation of genes that indirectly promote disease, such as those involved in nutrient, sugar, or iron metabolism. Based on evidence regarding $X$. oryzae pv. oryzae proteins in the AvrBs3 family, it is tempting to speculate that such a Xa5 interactor could be a transcriptional activator of eukaryotic genes.

Indeed, TFIIA $\gamma$ has been reported to bind to transcriptional activators (Kraemer et al. 2006; Kobayashi et al. 1995). As mentioned above, TFIIA helps stabilize the TFIID-DNA complex (Chi et al. 1995; Lieberman and Berk 1994; Wang et al. 1992). The stability of this complex is important for gene tran- scription and, thus, provides a good target for transcriptional regulators (Kashanchi et al. 1996; Kobayashi et al. 1995; Stargell and Struhl 1995; Xie et al. 2000). In yeast, TFIIA $\gamma$ directly interacts with transcriptional activators like the basic leucine zip factor Yap1 (Kraemer et al. 2006), herpes simplex virus VP16, and Epstein-Barr virus Zta (Kobayishi et al. 1995). TFIIA has also been reported to be involved in tissuespecific gene expression. In Drosophila spp., an isoform of TFIIA $\gamma$ is involved in photoreceptor development (Zeidler et al. 1996).

Because rice has two copies of TFIIA $\gamma$, it is of interest to determine whether only one or whether both paralogs are implicated in the disease response. Recently, Sugio and colleagues (2005) identified OsTFIIA $\gamma 1$ in a screen for genes upregulated by the virulent Philippine race PXO99 ${ }^{\mathrm{A}}$. Infection of rice with $X$. oryzae pv. oryzae $\mathrm{PXO} 99^{\mathrm{A}}$ results in the upregulation of TFIIA $\gamma 1$ but not $X a 5^{\mathrm{R} / \mathrm{S}}$, while inoculation of $x a 5$-containing rice with $X$. oryzae pv. oryzae race PXO86 results in no change in expression level of either TFIIA $\gamma 1$ or TFIIA $\gamma 5\left(X a 5^{R / S}\right)$ (Iyer and McCouch 2004; Jiang et al. 2006). This raises the possibility that PXO99 ${ }^{\mathrm{A}}$ targets TFIIA $\gamma 1$ to promote disease. These exciting results suggest that there may be a complex relationship between the paralogs and the disease response.

Could TFIIA mediate resistance to other Xanthomonas species that infect plants or animals? Thus far, a role for TFIIA $\gamma$ in disease resistance has not been reported in any other system. Interestingly, a 10-amino acid peptide of the large TFIIA subunit, mutated in one amino acid, activated T-cells in patients with celiac disease, an autoimmune disorder in which patients cannot absorb the gliadin proteins found in specific cereals (Kumar et al. 2002). This mutant peptide was created in the lab and is not found in native human populations. Nonetheless, this study showed that a mutation in the large subunit of TFIIA could activate the human immune system, suggesting that TFIIA may be involved in pathways other than RNA polymerase II transcription. Further, a human isoform of the large subunit TFIIA-ALF is expressed specifically in male testis (Upadhyaya et al. 1999), and an isoform of the Drosophila small subunit plays a role in photoreceptor development (Zeidler et al. 1996). Work in yeast has shown that some TFIIA $\gamma$ mutations result in a wild-type phenotype (Kang et al. 1995; Warfield et al. 2004). Hence, although TFIIA $\gamma$ is a single-copy gene in humans, some mutations might provide additional functionality without disrupting its essential function. These findings are significant in light of the observed similarities between animal immunity and plant resistance (Ausubel 2005; Fluhr and Kaplan-Levy 2002; Nurnberger and Brunner 2002; Nurnberger et al. 2004; Staskawicz et al. 2001; Zipfel and Felix 2005). Together, these reports indicate that TFIIA is not a typical GTF and suggest the possibility that TFIIA $\gamma$ might play a role in disease resistance other than rice $\mathrm{BB}$.

xa13. The recessive gene $x a 13$, derived from the BJ1 group of rices, provides resistance to race $6 X$. oryzae pv. oryzae, PXO99A ${ }^{\mathrm{A}}$, the same broadly virulent Philippine race described above in relation to OsTFIIA $\gamma 1$ (Ogawa et al. 1987). Resistant (xa13) and susceptible (Xa13) alleles each encode unique $307-$ amino acid plasma membrane-localized proteins (Chu et al. 2006) that show $68 \%$ sequence similarity to the MtN3 protein induced by Rhizobium spp. in legume nodule development.

Examination of gene expression in leaves showed that $\mathrm{Xa13}$ is upregulated upon pathogen infection but not when mockinoculated with water. Promoter- $\beta$-glucuronidase fusions demonstrated that $\mathrm{Xa13}$ was expressed in the parenchyma cells that surround xylem elements of leaves. Xal3 induction leads to susceptibility, as the recessive resistant allele was not upregulated upon pathogen challenge. In uninoculated plants, both alleles were expressed predominantly in the panicles and an- 
thers, suggesting a role for $X a 13^{R / S}$ in developmental processes. One amino acid substitution was found between the susceptible and resistant proteins of the susceptible variety IR24 and its resistant NIL IRBB13 (which carries $x a 13$ ). Examination of proteins encoded by other Xa13 and $x a 13$ alleles suggested that this amino acid was not the functional amino acid polymorphism (Chu et al. 2006). Further investigation identified a variable area in the -69 to -86 region of the promoter. All 11 xal3-carrying lines examined had an insertion, deletion, or substitution (compared with Xa13 lines) in this area. Mutations in this region appeared to eliminate the induction of Xa13 during pathogen inoculation (Chu et al 2006). Thus, expression levels of the alleles appear to be key to resistance. In support of this, silencing the dominant susceptible allele resulted in resistance, while silencing the recessive resistant allele yielded even higher levels of resistance, as measured by reduced lesion length. Additional work showed that this locus is critical to viable pollen development, as plants silenced for either allele were male-sterile (Chu et al. 2006). Understanding how the developmental and disease-resistant pathways intersect is the next exciting step in this system.

\section{Recessive resistance or dominant susceptibility?}

Are $x a 5$ and $x a 13$ really resistant genes or are they simply mutant forms of susceptibility alleles? This is an important distinction, as it has implications regarding plant defense and disease control. For example, if susceptibility is an active process in which a host gene is targeted by a bacterial protein to induce susceptibility, then recessive resistance may be a passive response defined more by the lack of susceptibility than the activation of defense signaling pathways.

If this were the case with $x a 5$ and $x a 13$, we might expect responses to these genes to differ from those commonly observed in $R$ gene systems. Indeed, though investigations of $x a 5$ and xal3 resistance mechanisms are still in the early stages, several points of evidence already suggest that these genes have atypical $R$ gene responses. First, neither gene shows a typical hypersensitive response in the resistant reaction. A delayed and somewhat weak HR becomes apparent 48 to $72 \mathrm{~h}$ after infiltration of $X$. oryzae pv. oryzae PXO86 in rice leaves expressing xa5 (A. J. Bogdanove, personal communication). Inoculation of IRBB13, which carries only the xal3 gene for BB resistance, with the incompatible $X$. oryzae pv. oryzae PXO99 ${ }^{\mathrm{A}}$ does not result in the browning seen after inoculation with an incompatible PXO99 ${ }^{\mathrm{A}}$ strain carrying the effector $a v r X a 7$-sacB50 (Yang et al. 2006). Second, at least for $x a 13$, defense gene expression is altered. POX22.3, a peroxidase gene usually highly induced in the rice defense response, is not induced in IRBB13 when inoculated with incompatible $\mathrm{PXO} 99^{\mathrm{A}}$ but is induced in the interaction with the incompatible PXO99 ${ }^{\mathrm{A}}(\operatorname{avrXa7}$-sacB50) strain (Yang et al. 2006). Additionally, several genes not previously associated with defense pathways showed differential expression in the xal3 response (Chu et al. 2004). Resistant responses due to $x a 5$ are currently under investigation.

These atypical reactions suggest that at least some recessive $R$ genes might more aptly be thought of as mutations of dominant susceptibility (' $\mathrm{S}$ ') alleles. Indeed both $\mathrm{Xa13}$ and $\mathrm{Xa5}$ may act as susceptibility alleles. When transformed into homozygous resistant lines, each causes disease, and bacteria are more virulent as evaluated by lesion length on plants expressing $X a 5$ or $X a 13$ than on plants expressing the resistant alleles (Chu et al. 2006; A. Iyer-Pascuzzi and S. R. McCouch, unpublished). Moreover, recent exciting work by Yang and colleagues (2006) suggests that susceptibility alleles like Xa13 might be targeted by type III effectors in a gene-for-gene manner. We postulate that there are two classes of recessive $R$ genes, those like $R R S 1-R$ that do not have corresponding ' $\mathrm{S}$ ' alleles (dis- cussed above) and those like $x a 5$ and $x a 13$ that are likely to be mutated forms of ' $S$ ' genes. Further, we hypothesize that i) ' $S$ ' genes are necessary for pathogen virulence, ii) ' $S$ ' genes may function in a gene-for-gene manner with bacterial effectors, and iii) ' $S$ ' genes are likely to be essential host proteins.

In a search for host susceptibility genes induced by $X$. oryzae pv. oryzae, Yang and colleagues (2006) used wholegenome-based microarray analysis of rice cultivar Nipponbare (subpopulation japonica) inoculated with the highly virulent race PXO99 ${ }^{\mathrm{A}}$ and a PXO99 ${ }^{\mathrm{A}}$ mutant, ME2. PXO99 ${ }^{\mathrm{A}}$ carries the TAL effector gene $p t h X o 1$, and strains mutated in this gene, such as ME2, are severely reduced in virulence (Yang and White 2004). One gene, Os $8 N 3$, was induced more than 100fold in Nipponbare leaves inoculated with PXO99 ${ }^{\mathrm{A}}$, as compared with those inoculated with the ME2 mutant, and was not induced when mock-inoculated with water. Plants silenced for Os8N3 were resistant to $\mathrm{PXO} 99^{\mathrm{A}}$. Additional analysis showed that $O s 8 N 3$ was allelic to $\mathrm{Xa13}$. Examination of the isolines IR24 and IRBB13 showed that PXO99 ${ }^{\mathrm{A}}$, which is highly virulent to IR24 but incompatible with IRBB13, could induce Os $8 N 3$ in IR24 but not in IRBB13 or in other cultivars containing $x a 13$. This induction and compatibility was dependent on the effector pthXol, as the mutant ME2 could not induce $O s 8 N 3$ in IR24 and was only weakly virulent. Reintroduction of pthXol restored both virulence and $O s 8 N 3$ upregulation to ME2, when inoculated on IR24. Further, introduction of the TAL effector $a v r X a 7$ [ME2( $a v r X a 7)$ ], a major virulence factor for $X$. oryzae pv. oryzae PXO86 (Bai et al. 2000; Yang et al. 2000), restored full virulence of ME2 on IR24 and IRBB13 but did not result in the upregulation of $O s 8 N 3$. Xa13/Os $8 N 3$, therefore, appears to be a gene-for-gene ' $S$ ' allele.

Yang and colleagues (2006) also demonstrated that the resistance affected by $\mathrm{Xa} 7$ is 'dominant' to the susceptibility induced by Xa13. PXO99 ${ }^{\mathrm{A}}(a v r X a 7)$ could induce Os8N3/Xa13 yet triggered a HR on plants carrying $X a 7$. Surprisingly, $\mathrm{PXO}^{\mathrm{A}}(a v r X a 7)$ was also virulent to IRBB13. Therefore, the resistance due to $x a 13$ can be overcome by the addition of a virulence factor rather than the loss of an avirulence allele, further supporting the conclusion that $x a 13$ is not a typical $R$ gene (Yang et al. 2006).

\section{Recessive resistance due to a mutation in an essential host protein?}

Intriguingly, both $x a 5$ and $x a 13$, though completely different in function, encode essential host proteins. TFIIA $\gamma$ is an evolutionarily conserved protein necessary for efficient transcription across plant and animal kingdoms and for effective responses to oxidative stress (Aoyagi and Wassarman 2000; Kraemer et al. 2006; Orphanides et al.1996). Xa13 is essential for pollen development and, hence, reproduction in this self-pollinating species, as silencing of $\mathrm{Xa1} 3^{R / S}$ results in abortive pollen (Chu et al. 2006). Thus, for both $x a 5$ and $x a 13$, resistance is the result of a mutation affecting a vital host gene that has acquired a new function (resistance) but most likely still functions in its 'normal' capacity.

Fraser $(1986,1990)$ hypothesized that recessive viral $R$ genes were due to a mutation in a host protein necessary for viral multiplication. Adapting Fraser's concept to plant-bacterial interactions yields the hypothesis that plant recessive $R$ genes are due to a mutation in an essential host protein necessary for bacterial virulence. This hypothesis suggests that the probability of gaining a new function while retaining an original, essential function via a single mutation is a very rare event. This helps explain why there are fewer known recessively inherited genes. Even in viral systems, most recessive $R$ genes appear to encode isoforms of just one or two proteins (discussed above). 


\section{Are recessive $\boldsymbol{R}$ genes durable?}

$R$ genes that have been successfully used for many years in a large population over a large area conducive for disease development are thought to be durable (Johnson 1984). Unfortunately, many $R$ genes 'break down', in part due to mutation of effector genes (Leach et al. 2001). Understanding how to prevent this by identifying potentially durable $R$ genes is key to preventing disease outbreaks on $R$-gene-containing cultivars. Might recessive $R$ genes be a place to start? Since dominant $S$ genes appear to be important for bacterial virulence, mutations in corresponding effector genes may carry a fitness cost (Leach et al. 2001). This may result in durable recessive $R$ genes.

Unfortunately, little information exists as to the durability of $x a 5$ or $x a 13$ when used alone in rice cultivars. However, several studies have shown that when used in combination with other $R$ genes, both $x a 5$ and $x a 13$ provide stronger and broader levels of resistance than when used alone (Huang et al. 1997; Shanti et al. 2001; Singh et al. 2001; Sridhar et al. 1999; Yoshimura et al. 1995). For example, though the most common $X$. oryzae pv. oryzae haplotype identified in Eastern India could overcome $\mathrm{Xa3}, \mathrm{Xa} 4$, and $x a 5$ when deployed individually and several pathotypes were also virulent to $x a 13$ and $X a 21$, cultivars with gene combinations of $X a 4+x a 5$, $x a 5+X a 21$, or $X a 4+x a 5+X a 21$ were resistant to all isolates tested (Shanti et al. 2001). Complementary gene action among two or more of the Xa4, xa5, Xa21, or $x a 13$ genes has been observed in four additional studies (Adhikari et al. 1999; Huang et al.1997; Sridhar et al. 1999; Yoshimura et al. 1995). In all four studies, cases in which $x a 5$ was used with $x a 13, X a 21$, or $\mathrm{Xa} 4$ resulted in increased resistance (in terms of number of isolates, degree of infection severity, or both) to $X$. oryzae pv. oryzae strains.

\section{Perspectives.}

Work on the molecular mechanisms of plant recessive genefor-gene resistance to bacterial pathogens is just beginning. Though the identification of $x a 5$ and $x a 13$ has stimulated research in this area, much more data are needed. Biochemical, genetic, and cell biology studies will be important for understanding how $x a 5$ and $x a 13$ lead to resistance. The isolation of additional recessive $R$ genes will reveal whether they are typically variants of ' $S$ ' alleles essential for a host function and will address whether most fall into one of the classic wellcharacterized $R$ gene classes or encode new classes of proteins. The observation that an $S$ gene can act in a gene-for-gene manner suggests that these alleles might be direct targets for bacterial manipulation and may yield clues to pathogen control. Eventually it may be possible to predict which genes might be susceptibility alleles. The identification of natural variants in wild germplasm or through manipulation in the lab could then lead to novel disease-prevention strategies. Alternatively, combinations of recessive $R$ genes may provide durable resistance. Future work will hopefully center around the mechanisms by which these intriguing loci function in both resistance and susceptibility.

\section{LITERATURE CITED}

Adhikari, T., and Shrestha, S. M. 1990. Distribution of bacterial blight (BB) in Nepal. Int. Rice Res. Notes 15:4, 22-23.

Adhikari, T. B., Mew, T. W., and Teng, P. S. 1994a. Progress of bacterial blight on rice culitvars carrying different $\mathrm{Xa}$ genes for resistance in the field. Plant Dis. 78:73-77.

Adhikari, T. B., Mew, T. W., and Teng, P. S. 1994b. Phenotypic diversity of Xanthomonas oryzae pv. oryzae in Nepal. Plant Dis. 78:68-72.

Adhikari, T. B., Basnyat, R. C., and Mew, T. W. 1999a. Virulence of Xanthomonas oryzae pv. oryzae on rice lines containing single resistance genes and gene combinations. Plant Dis. 83:46-50.

Akhtar, M. A., and Akram, M. 1987. Evaluation of national uniform rice yield trial 1985 against bacterial blight (BB) in Pakistan. Int. Rice Res. Notes 12:6, 12

Albar, L., Bangratz-Reyser, M., Hebrard, E., Ndjiondjop, M. N., Jones, M., and Ghesquiere, A. 2006. Mutations in the eIF(iso)4G translation initiation factor confer high resistance of rice to Rice yellow mottle virus. Plant J. 47:417-26.

Alfano, J. R., and Collmer, A. 2004. Type III secretion system effector proteins: Double agents in bacterial disease and plant defense. Annu, Rev. Phytopathol, 42:385-414.

Aoyagi, N., and Wassarman, D. A. 2000. Genes encoding Drosophila melanogaster RNA polymerase II general transcription factors: A diversity of TFIIA and TFIID components contributes to gene-specific transcriptional regulation. J. Cell Biol. 150:F45-50.

Ausubel, F. M. 2005. Are innate immune signaling pathways in plants and animals conserved? Nature Immunol. 6:973-979.

Bai, J., Choi, S. H., Ponciano, G., Leung, H., and Leach, J. E. 2000. Xanthomonas oryzae pv. oryzae avirulence genes contribute differently and specifically to pathogen aggressiveness. Mol. Plant-Microbe Interact. 13:1322-1329.

Belkhadir, Y., Subramaniam, R., and Dangl, J. L. 2004. Plant disease resistance protein signaling: NBS-LRR proteins and their partners. Curr. Opin. Plant Biol. 7:391-399.

Blair, M. W., Garris, A. J., Iyer, A. S., Chapman, B., Kresovich, S., and McCouch, S. R. 2003. High resolution genetic mapping and candidate gene identification at the $x a 5$ locus for bacterial blight resistance in rice (Oryza sativa L.). Theor. Appl. Genet. 107:62-73.

Bleichenbacher, M., Tan, S., Richmond, T. J. 2003. Novel interactions between the components of human and yeast TFIIA/TBP/DNA complexes. J. Mol. Biol. 332:783-93.

Burke, C., Yu, X. B., Marchitelli, L., Davis, E. A., and Ackerman, S. 1990. Transcription factor IIA of wheat and human function similarly with plant and animal viral promoters. Nucleic Acids Res. 18:3611-3620.

Buschges, R., Hollricher, K., Panstruga, R., Simons, G., Wolter, M., Frijters, A., van Daelen, R., van der Lee, T., Diergaarde, P., Groenendijk, J., Topsch, S., Vos, P., Salamini, F., and Schulze-Lefert, P. 1997. The barley Mlo gene: A novel control element of plant pathogen resistance. Cell 88:695-705.

Chi, T., Lieberman, P., Ellwood, K., and Carey, M. 1995. A general mechanism for transcriptional synergy by eukaryotic activators. Nature 377:254-257.

Chu, Z., Ouyang, Y., Zhang, J., Yang, H., and Wang, S. 2004. Genomewide analysis of defense-responsive genes in bacterial blight resistance of rice mediated by the recessive $R$ gene $x a 13$. Mol. Genet. Genomics 271:111-120.

Chu, Z., Yuan, M., Yao, J., Ge, X., Yuan, B., Xu, C., Li, X., Fu, B., Li, Z., Bennetzen, J. L., Zhang, Q., and Wang, S. 2006. Promoter mutations of an essential gene for pollen development result in disease resistance in rice. Genes Dev. 20:1250-1255.

Deslandes, L., Olivier, J., Theulieres, F., Hirsch, J., Feng, D. X., BittnerEddy, P., Beynon, J., and Marco, Y. 2002. Resistance to Ralstonia solanacearum in Arabidopsis thaliana is conferred by the recessive $R R S 1-R$ gene, a member of a novel family of resistance genes. Proc. Natl. Acad. Sci. U.S.A. 99:2404-2409.

Devadath, S. 1992. Bacterial blight of paddy. Pages 158-185 in: Plant Diseases of International Importance: Diseases of Cereals and Pulses. U. S. Singh, A. N. Mukhopadhyay, J. Kumar, and H. S. Chaube, eds. Prentice-Hall, Inc., Englewood Cliffs, NJ, U.S.A.

Diaz-Pendon, J. A., Truniger, V., Nieto, C., Garcia-Mas, J., Bendahmane, A., and Aranda, M. A. 2004. Advances in understancing recessive resistance to plant viruses. Mol. Plant Pathol. 5:223-233.

Eamchit, S., and Mew, T. W. 1981. Comparison of virulence of Xanthomonas campestris pv. oryzae in Thailand and the Philippines. Plant Dis 66:556-559.

Fluhr, R., and Kaplan-Levy, R. N. 2002. Plant disease resistance: Commonality and novelty in multicellular innate immunity. Curr. Top. Microbiol. Immunol. 270:23-46.

Fraser, R. S. S. 1986. Genes for resistance to plant viruses. CRC Crit. Rev. Plant Sci. 3:257-294.

Fraser, R. S. S. 1990. The genetics of resistance to plant viruses. Annu. Rev. Phytopathol. 28:179-200.

Fujikawa, T., Ishihara, H., Leach, J. E., and Tsuyumu S. 2006. Suppression of defense response in plants by the avrBs3/pthA gene family of Xanthomonas spp. Mol. Plant-Microbe Interact. 19:342-349.

Geiger, J. H., Hahn, S., Lee, S., and Sigler, P. B. 1996. Crystal structure of the yeast TFIIA/TBP/DNA complex. Science 272:830-836.

Gu, K., Yang, B., Tian, D., Wu, L., Wang, D., Sreekala, C., Yang, F., Chu, Z., Wang, G.L., White, F. F., and Yin, Z. 2005. $R$ gene expression induced by a type-III effector triggers disease resistance in rice. Nature 435:1122-1125.

Gurlebeck, D., Thieme, F., and Bonas, U. 2006. Type III effector proteins 
from the plant pathogen Xanthomonas and their role in the interaction with the host plant. J. Plant Physiol. 163:233-255.

Hampsey, M. 1998. Molecular genetics of the RNA polymerase II general transcriptional machinery. Microbiol. Mol. Biol. Rev. 62:465-503.

Huang, N., Angeles, E. R., Domingo, J., Magpantay, G., Singh, S., Zhang, G., Kumaravedivel, N., Bennett, J., and Khush, G. S. 1997. Pyramiding of bacterial blight resistance genes in rice: Marker-assisted selection using RFLP and PCR. Theor. Appl. Genet. 95:313-320.

Iyer, A. S., and McCouch, S. R. 2004. The rice bacterial blight resistance gene $x a 5$ encodes a novel form of disease resistance. Mol. PlantMicrobe Interact. 17:1348-1354.

Jiang, G. H., Xia, Z. H., Zhou, Y. L., Wan, J., Li, D. Y., Chen, R. S., Zhai, W. X., Zhu, L. H. 2006. Testifying the rice bacterial blight resistance gene $x a 5$ by genetic complementation and further analyzing xa5 (Xa5) in comparison with its homolog TFIIAgamma1.Mol. Genet. Genomics. 275:354-66.

Johnson, R. 1984. A critical analysis of durable resistance. Annu. Rev. Phytopathol. 22:309-330.

Kang, B. C., Yeam, I., Frantz, J. D., Murphy, J. F., and Jahn, M. M. 2005a The pvrl locus in Capsicum encodes a translation initiation factor eIF4E that interacts with Tobacco etch virus VPg. Plant J. 42:392-405.

Kang, B. C., Yeam, I., and Jahn, M. M. 2005b. Genetics of plant virus resistance. Annu. Rev. Phytopathol. 43:581-621.

Kang, J. J., Auble, D. T., Ranish, J. A., and Hahn, S. 1995. Analysis of the yeast transcription factor TFIIA: Distinct functional regions and a polymerase II-specific role in basal and activated transcription. Mol. Cell Biol. 15:1234-1243.

Kang, M. S., and Singh, I. 1987. Some pathological and physiological diseases of rice in the Punjab. Int. Rice Research Notes12:6, 24.

Kashanchi, F., Khleif, S. N., Duvall, J. F., Sadaie, M. R., Radonovich, M F., Cho, M., Martin, M. A., Chen, S. Y., Weinmann, R., Brady, J. N. 1996. Interaction of human immunodeficiency virus type 1 Tat with a unique site of TFIID inhibits negative cofactor Dr1 and stabilizes the TFIID-TFIIA complex. J. Virol. 70:5503-10.

Khush, G. S., and Angeles, E. R. 1999. A new gene for resistance to race 6 of bacterial blight in rice, Oryza sativa. Rice Genetics Newsl. 16:92-93.

Kobayashi, N., Boyer, T. G., and Berk, A. J. 1995. A class of activation domains interacts directly with TFIIA and stimulates TFIIA-TFIID-promoter complex assembly. Mol. Cell Biol.15:6465-6473.

Kobayashi, N., Horn, P. J., Sullivan, S. M., Triezenberg, S. J., Boyer, T. G., and Berk, A. J. 1998. DA-complex assembly activity required for VP16C transcriptional activation. Mol. Cell Biol. 18:4023-4031.

Kraemer, S. M., Ranallo, R. T., Ogg, R. C., Stargell, L. A. 2001. TFIIA interacts with TFIID via association with TATA-binding protein and TAF40. Mol. Cell Biol. 21:1737-1746.

Kraemer, S. M., Goldstrohm, D. A., Berger, A., Hankey, S., Rovinsky, S. A., Scott, Moye-Rowley, W., Stargell, L. A. 2006. TFIIA plays a role in the response to oxidative stress. Eukaryot. Cell 5, :1081-90.

Kumar, R., Eastwood, A. L., Brown, M. L., and Laurie, G. W. 2002. Human genome search in celiac disease: Mutated gliadin T-cell-like epitope in two human proteins promotes T-cell activation. J. Mol. Bio. 319:593-602.

Leach, J. E., Vera Cruz, C. M., Bai J., and Leung, H. 2001. Pathogen fitness penalty as a predictor of durability of disease resistance genes. Annu. Rev. Phytopathol. 39:187-224.

Lee, B. M., Park, Y. J., Park, D. S., Kang, H. W., Kim, J. G., Song, E. S., Park, I. C., Yoon, U. H., Hahn, J. H., Koo, B. S., Lee, G. B., Kim, H., Park, H. S., Yoon, K. O., Kim, J. H., Jung, C. H., Koh, N. H., Seo, J. S., and Go, S. J. 2005. The genome sequence of Xanthomonas oryzae pv oryzae KACC10331, the bacterial blight pathogen of rice. Nucleic Acids Res. 33:577-586.

Lee, K. S., Rasabandith, S., Angeles, E. R., and Khush, G. S. 2003. Inheritance of resistance to bacterial blight in 21 cultivars of rice. Phytopathology 93:147-152.

Leonard, S., Chisholm, J., Laliberte, J. F., Sanfacon, H. 2002. Interaction in vitro between the proteinase of Tomato ringspot virus (genus Nepovi$r u s$ ) and the eukaryotic translation initiation factor iso 4E from Arabidopsis thaliana. J. Gen. Virol. 83:2085-2089.

Lieberman, P. M., and Berk, A. J. 1994. A mechanism for TAFs in transcriptional activation: Activation domain enhancement of TFIIDTFIIA--promoter DNA complex formation. Genes Dev. 8:995-1006.

Liu, Q., Gabriel, S. E., Roinick, K. L., Ward, R. D., andArndt, K. M. 1999. Analysis of TFIIA function in vivo: Evidence for a role in TATA-binding protein recruitment and gene-specific activation. Mol. Cell Biol. 19:8673-8685.

Ma, D., Olave, I., Merino, A., and Reinberg, D. 1996. Separation of the transcriptional coactivator and antirepression functions of transription factor IIA. Proc. Natl. Acad. Sci. U.S.A. 93:6583-6588.

Marois, E., Van den Ackerveken, G., and Bonas, U. 2002. The Xanthomonas type III effector protein AvrBs3 modulates plant gene expression and induces cell hypertrophy in the susceptible host. Mol. PlantMicrobe Interact. 15:637-646.

Martin, G. B., Bogdanove, A. J., and Sessa, G. 2003. Understanding the functions of plant disease resistance proteins. Annu. Rev. Plant Biol. 54:23-61.

McHale, L., Tan, X., Koehl, P., and Michelmore, R. W. 2006. Plant NBSLRR proteins: Adaptable guards. Genome Biol. 7:212.

Mew, T. W. 1987. Current status and future prospects of research on bacterial blight of rice. Annu. Rev. Phytopathol. 25:359-382.

Mew, T. W. 1993. Xanthomonas oryzae pathovars on rice: Cause of bacterial blight and bacterial leaf streak. Pages in 30-39 in: Xanthomonas. J. G. Swings and E. L. Civerolo, eds. Chapman and Hall, London.

Mew T. W., and Majiid, A. 1977 Bacterial blight of rice in Pakistan. IRRN $2: 1,5$.

Mizukami T., and Wakimoto S. 1969. Epidemiology and control of bacterial leaf blight of rice. Annu. Rev. Phytopathol. 7:51-72.

Mew T. W., Vera Cruz C. M., and Reyes R. C. 1981. Characterization of resistance in rice to bacterial blight. Ann. Phytopath. Soc. Japan 47:5867.

Mew, T. W., Vera Cruz, C. M., and Medalla, E. S. 1992. Changes in race frequency of Xanthomonas oryzae pv. oryzae in response to rice cultivars planted in the Philippines. Plant Dis. 76:1029-1032.

Mudgett, M. B. 2005. New insights to the function of phytopathogenic bacterial type III effectors in plants. Annu. Rev. Plant. Biol. 56:509531.

Nakai, H., Nakamura, S., Kuwahara, S, and Saito, M. 1988. Genetic studies of an induced rice mutant resistant to multiple races of bacterial leaf blight. Rice Genetic Newslet. 5:101.

Nakai, H., Nakamura, K., Kuwahara, S., and Saito, M. 1990. A new gene developed through mutagenesis for resistance of rice to bacterial leaf blight Xanthomonas campestris pv. oryzae. J. Agricul. Sci. 114:219-224.

Nino-Liu, D. O., Ronald, R., and Bogdanove, A. 2006. Xanthomonas oryzae pathovars: Model pathogens of a model crop. Mol. Plant Path. 7:303-324.

Nurnberger, T., and Brunner, F. 2002. Innate immunity in plants and animals: Emerging parallels between the recognition of general elicitors and pathogen-associated molecular patterns. Curr. Opin. Plant Biol. $5: 318-324$

Nurnberger, T., Brunner, F., Kemmerling, B., and Piater, L. 2004. Innate immunity in plants and animals: Striking similarities and obvious differences. Immunological Rev. 198:249-266.

Ochiai, H., Horino, O., Miyajima, K., and Kaku, H. 2000. Genetic diversity of Xanthomonas oryzae pv. oryzae strains from Sri Lanka. Phytopathology 90:415-421.

Ogawa, T. 1996. Monitoring race distribution and identification of genes for resistance to bacterial leaf blight. Pages 456-459 in: Rice Genetics III, Proceedings of the Third International Rice Genetics Symposium. G. S. Khush, ed. International Rice Research Institute, Manila, Philippines.

Ogawa, T., Lin, L., Tabien, R. E., and Khush, G. S. 1987. A new recessive gene for resistance to bacterial blight of rice. Rice Genetic Newsl. 4:98100.

Ogawa, T., Yamamoto, T., Khush, G. S., Mew, T. W., and Kaku, H. 1988. Near-isogenic lines as international differentials for resistance to bacterial blight of rice. Rice Genetic Newsl. 5:106-109.

Orphanides, G., Lagrange, T., and Reinberg, D. 1996. The general transcription factors of RNA polymerase II. Genes Dev. 10:2657-2683.

Ozer, J., Moore P. A., Bolden A. H., Lee A., Rosen C. A., and Lieberman P. M. 1994. Molecular cloning of the small (gamma) subunit of human TFIIA reveals functions critical for activated transcription. Genes Dev. 8:2324-2335

Ozer, J., Bolden, A. H., and Lieberman, P. M. 1996. Transcription factor IIA mutations show activator-specific defects and reveal a function distinct from stimulation of TBP-DNA binding. J. Biol. Chem. 271, 11182 11190.

Ozer, J., Mitsouras, K., Zerby, D., Carey, M., and Lieberman, P. M. 1998a. Transcription factor IIA derepresses TATA-binding protein (TBP)-associated factor inhibition of TBP-DNA binding. J. Biol. Chem. 273:14293-14300.

Ozer, J., Lezina, L. E., Ewing, J., Audi, S., and Lieberman, P. M. 1998b. Association of transcription factor IIA with TATA binding protein is required for transcriptional activation of a subset of promoters and cell cycle progression in Saccharomyces cerevisiae. Mol. Cell. Biol. 18:2559-2570.

Petpisit, V., Khush, G. S., and Kauffman, H. E. 1977. Inheritance of resistance to bacterial blight in rice. Crop Sci. 17:551-554.

Raina, G. L., Sidhu, G. S., and Saini, P. K. 1981. Rice bacterial blight status in the Punjab, India. International Rice Research Notes 6:5, 12.

Robaglia, C., and Caranta, C. 2006. Translation initiation factors: A weak link in plant RNA virus infection. Trends Plant Sci. 11:40-45. 
Robinson, M. M., Yatherajam, G., Ranallo, R. T., Bric, A., Paule, M. R., Stargell, L. A. 2005. Mapping and functional characterization of the TAF11 interaction with TFIIA. Mol. Cell Biol. 25:945-57.

Roeder, R. G. 1996. Role of general and gene-specific cofactors in the regulation of eukaryotic transcription. Trends Biochem. Sci. 21:327-335.

Shanti, M. L., George, M. L. C., Vera Cruz C. M., Bernardo M. A., Nelson R. J., and Leung H. 2001. Identification of resistance genes effective against rice bacterial blight pathogen in Eastern India. Plant Dis. 85:506-512.

Shen, Y., and Ronald, P. 2002. Molecular determinants of disease and resistance in interactions of Xanthomonas oryzae pv. oryzae and rice. Microbes Infect. 4:1361-1367.

Sidhu, G. S., Khush, G. S., and Mew, T. W. 1978. Genetic analysis of bacterial blight resistance in seventy-four cultivars of rice, Oryza sativa L. Theor. Appl. Genet. 53:105-111.

Singh, K., Vikal, Y., Singh, S., Leung, H., Dhaliwal, H. S., and Khush, G. S. 2002. Mapping of bacterial blight resistance gene $x a 8$ using microsatellite markers. Rice Genet. Newsl. 19:94-96.

Singh S., Sidhu J. S., Huang N., Vikal Y., Li Z., Brar D. S., Dhaliwal H. S., and Khush G. S. 2001. Pyramiding three bacterial blight resistance genes (xa5, xa13 and $\mathrm{Xa21}$ ) using marker-assisted selection into indica rice cultivar PR106. Theor. Appl. Genet. 102:1011-1015.

Sirisantana, W., Nilpanit, N., Phawichit, S., Kiatsuranont, P., and Disthaporn, S. 1984. Yield loss to bacterial blight (BB) in central Thailand. International Rice Res. Notes 9:6, 10, 11.

Song, W., Wang, G., Chen, L., Kim, H., Pi, L., Holsten, T., Gardner, J., Wang, B., Zhai, W., Zhu, L., Fauquet, C., and Ronald P. 1995. A receptor kinase-like protein encoded by the rice disease resistance gene, Xa21. Science:1804-1806.

Sridhar, R. 2002. Use of molecular tools for understanding bacterial blight pathogen populations of rice and usefulness of disease resistance genes. Indian Phytopathol. 55:417-429.

Sridhar, R., Reddy, J. N., Singh, U. D., and Agrawal, P. K. 1999. Usefulness of combinations of bacterial blight resistance genes at Cuttack, Orissa, India. Rice Genet. Newsl. 16:24-25.

Stargell, L. A., and Struhl K. 1995. The TBP-TFIIA interaction in the response to acidic activators in vivo. Science 269:75-78.

Stargell, L. A., Moqtaderi, Z., Dorris, D. R., Ogg, R. C., and Struhl K. 2000. TFIIA has activator-dependent and core promoter functions in vivo. J. Biol. Chem. 275:12374-12380.

Staskawicz, B. J., Mudgett, M. B., Dangl, J. L., and Galan, J. E. 2001. Common and contrasting themes of plant and animal diseases. Science 292:2285-2289.

Sugio, A., Yang, B., and White, F. F. 2005. Characterization of the hrpF pathogenicity peninsula of Xanthomonas oryzae pv. oryzae. Mol PlantMicrobe Interact 18:546-554.

Sun, X., Cao, Y., Yang, Z., Xu, C., Li, X., Wang, S., and Zhang, Q. 2004 Xa26, a gene conferring resistance to Xanthomonas oryzae pv. oryzae in rice, encodes an LRR receptor kinase-like protein. Plant J. 37:517-527.

Swarup, S., De Feyter, R., Brlansky, R. H., and Gabriel, D. W. 1991. A pathogenicity locus from Xanthomonas citri enables starins from several pathovars of Xanthomonas campestris to elicit canker-like lesions on citrus. Phytopathology 81:802-809

Szurek, B., Marois, E., Bonas, U., and Van den Ackerveken, G. 2001. Eukaryotic features of the Xanthomonas type III effector AvrBs3: Protein domains involved in transcriptional activation and the interaction with nuclear import receptors from pepper. Plant J. 26:523-534.

Tan, S., Hunziker, Y., Sargent, D. F., and Richmond, T. J. 1996. Crystal structure of a yeast TFIIA/TBP/DNA complex. Nature 381:127-134.

Taura, S., Ogawa, T., Yoshimura, A., Ikeda, R., and Omura, T. 1991. Identification of a recessive resistance gene in induced mutant line XM5 of rice to rice bacterial blight. Japan J. Breed. 43:427-432.

Taura, S., Ogawa, T., Yoshimura, A., Ikeda, R., and Iwata, N. 1992. Identification of a recessive resistance gene to rice bacterial blight of mutant line XM6, Oryza sativa L. Japan J. Breed. 42:7-13.

Upadhyay, R. K. 1985. Rice disease status in India. International Rice Res. Notes 10:5, 17-18

Upadhyaya, A. B., Lee, S. H., and DeJong, J. 1999. Identification of a general transcription factor TFIIA alpha/beta homolog selectively expressed in testis. J. Biol. Chem. 274:18040-18048.

van Kim, P., Thi Nghiem, N., Len, L., and Ngoc Kinh, D. 1981. Survey of rice diseases in the Vietnamese Mekong Delta from 1978 to 1980. IRRN 6:5, 14-15.

Wang, W., Gralla, J. D., and Carey, M. 1992. The acidic activator GAL4AH can stimulate polymerase II transcription by promoting assembly of a closed complex requiring TFIID and TFIIA. Genes Dev. 6:1716-1727.

Warfield, L., Ranish, J. A., and Hahn, S. 2004. Positive and negative functions of the SAGA complex mediated through interaction of Spt8 with TBP and the N-terminal domain of TFIIA. Genes Dev 18: 1022-34.

Xie, J., Collart, M., Lemaire, M., Stelzer, G., and Meisterernst, M. 2000. A single point mutation in TFIIA suppresses NC2 requirement in vivo. EMBO (Eur. Mol. Biol. Organ.) J. 19:672-682

Yang, B., and White, F. F. 2004. Diverse members of the AvrBs3/PthA family of type III effectors are major virulence determinants in bacterial blight disease of rice. Mol. Plant-Microbe Interact. 17:1192-1200.

Yang, B., Zhu, W., Johnson, L. B., and White, F. F. 2000. The virulence factor AvrXa7 of Xanthomonas oryzae pv. oryzae is a type III secretion pathway-dependent nuclear-localized double-stranded DNA-binding protein. Proc. Natl. Acad. Sci. U.S.A. 97:9807-9812.

Yang, B., Sugio, A., and White, F. F. 2006. Os $8 N 3$ is a host disease-susceptibility gene for bacterial blight of rice. Proc. Natl. Acad. Sci. U.S.A 103:10503-10508.

Yoshii, M., Nishikiori, M., Tomita, K., Yoshioka, N., Kozuka, R., Naito, S., and Ishikawa, M. 2004. The Arabidopsis Cucumovirus multiplication 1 and 2 loci encode translation initiation factors $4 \mathrm{E}$ and $4 \mathrm{G}$. J. Virol. 78:6102-6111.

Yoshimura, S., Yoshimura, A., Iwata, N., McCouch, S. R., Abenes, M. L. Baraoidan, M. R., Mew, T. W., and Nelson, R. J. 1995. Tagging and combining bacterial-blight resistance genes in rice using RAPD and RFLP markers. Mol. Breed. 1:375-387.

Yoshimura, S., Yamanouchi, U., Katayose, Y., Toki, S., Wang, Z. X., Kono, I., Kurata N., Yano, M., Iwata, N., and Sasaki T.1998. Expression of $\mathrm{Xal}$, a bacterial blight-resistance gene in rice, is induced by bacterial inoculation. Proc. Natl. Acad. Sci. U.S.A. 95:1663-1668.

Zeidler, M. P., Yokomori, K., Tjian, R., and Mlodzik, M. 1996. Drosophila TFIIA-S is up-regulated and required during Ras-mediated photoreceptor determination. Genes Dev. 10:50-59.

Zhu, W., Yang, B., Chittoor, J. M., Johnson, L. B., and White, F. F. 1998. AvrXa10 contains an acidic transcriptional activation domain in the functionally conserved $\mathrm{C}$ terminus. Mol. Plant-Microbe Interact. 11:824-832.

Zhu, W., Yang, B., Wills, N., Johnson, L. B., and White, F. F. 1999. The C terminus of AvrXa10 can be replaced by the transcriptional activation domain of VP16 from the Herpes simplex virus. Plant Cell 11:1665-1674.

Zipfel, C., and Felix, G. 2005. Plants and animals: A different taste for microbes? Curr. Opin. Plant Biol. 8:353-360. 